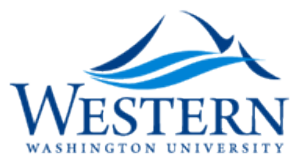

Western Washington University

Western CEDAR

2017

\title{
Year-round Algal Toxin Exposure in Free-ranging Sea Lions
}

\author{
Adrianne M.Akmajian \\ Jonathan J. Scordino \\ Alejandro Acevedo-Gutiérrez \\ Western Washington University, alejandro.acevedo-gutierrez@wwu.edu
}

Follow this and additional works at: https://cedar.wwu.edu/biology_facpubs

Part of the Biology Commons

\section{Recommended Citation}

Akmajian, Adrianne M.; Scordino, Jonathan J.; and Acevedo-Gutiérrez, Alejandro, "Year-round Algal Toxin Exposure in Free-ranging Sea Lions" (2017). Biology Faculty and Staff Publications. 60.

https://cedar.wwu.edu/biology_facpubs/60 


\title{
Year-round algal toxin exposure in free-ranging sea lions
}

\author{
Adrianne M. Akmajiann ${ }^{1,2, *}$, Jonathan J. Scordino ${ }^{1}$, Alejandro Acevedo-Gutiérrez ${ }^{2}$ \\ ${ }^{1}$ Makah Fisheries Management, Neah Bay, WA 98357, USA \\ ${ }^{2}$ Department of Biology, Western Washington University, Bellingham, WA 98225, USA
}

\begin{abstract}
Harmful algal bloom toxins cause illness and mortality in marine mammals worldwide, yet the potential for year-round exposure to these toxins has not previously been studied. We measured concentrations of domoic acid and saxitoxin in scats from Steller sea lions Eumetopias jubatus ( $\mathrm{n}=383$ scats) and California sea lions Zalophus californianus ( $\mathrm{n}=125$ scats) over a $2 \mathrm{yr}$ period. Toxin concentrations in the scats were compared to the prey remains in the scats and to concentrations in nearshore bivalves. Saxitoxin was detected in $45 \%$ and domoic acid was detected in $17 \%$ of all scats tested, and both toxins were detected in all seasons and months of the year. A variety of benthic and pelagic fish were significantly associated with toxins in sea lion scats, including prey with low occurrence in the sea lions' diet. Toxins detected in winter scats confirm that US West Coast marine mammals are exposed to domoic acid and saxitoxin through their prey outside of the expected algal bloom seasons.
\end{abstract}

KEY WORDS: Year-round $\cdot$ Harmful algal blooms $\cdot$ HABs $\cdot$ Saxitoxin $\cdot$ Domoic acid $\cdot$ Eumetopias jubatus $\cdot$ Zalophus californianus $\cdot$ Diet analysis

\section{INTRODUCTION}

Harmful algal blooms (HABs) are increasing worldwide and have led to mortalities of both humans and marine wildlife, including marine mammals (Fire \& Van Dolah 2012). This trend is particularly concerning for declining and depleted wildlife populations (Durbin et al. 2002), providing the need to understand what factors most influence exposure to these toxins. Marine mammal exposure to algal toxins has been examined through sampling prey and fecal remains of actively foraging or live-captured animals (Doucette et al. 2006, Lefebvre et al. 2016), plankton and nearshore bivalves in areas near mortality events (Scholin et al. 2000), and feces or stomach contents of ill or deceased animals (Lefebvre et al. 1999, 2010). However, the potential for year-round exposure through the food web has not been examined.

Two of the phytoplankton taxa implicated in marine mammal mortalities are Pseudo-nitzschia spp.

\footnotetext{
${ }^{*}$ Corresponding author: aakmajian@gmail.com
}

diatoms and Alexandrium spp. dinoflagellates, which produce domoic acid and paralytic shellfish toxins (PSTs; saxitoxin and a suite of congeners of which saxitoxin is the most toxic), respectively. The northwest coast of Washington State, USA, is a unique marine environment for studying domoic acid and PSTs, both of which impact state shellfish fisheries (Trainer et al. 2002, 2003). Situated at the northernmost extent of the California Current, the region is characterized by high phytoplankton biomass and primary productivity, driven by wind and topographic induced upwelling, the seasonally formed Juan de Fuca Eddy, and nutrient inputs from the Fraser and Columbia River outflows (MacFadyen et al. 2005). The Juan de Fuca Eddy, a cold-water gyre located offshore of the mouth of the Strait of Juan de Fuca, is a hotspot for Pseudo-nitzschia blooms (Trainer et al. 2002). The eddy forms in the spring and dissipates in the fall, and some waters escape from the eddy bringing toxins to the nearshore en-

() The authors 2017. Open Access under Creative Commons by Attribution Licence. Use, distribution and reproduction are unrestricted. Authors and original publication must be credited. 
vironment (MacFadyen et al. 2005). In contrast, Alexandrium blooms occur nearshore, typically in embayments with highly stratified waters, after water temperatures begin warming in the spring (Trainer et al. 2003). These differences in bloom dynamics likely result in different pathways of toxin exposure to top predators such as marine mammals. Toxin screening of marine mammals in Washington has detected sublethal concentrations of domoic acid in stranded cetacean and pinniped species (McCabe et al. 2016) and of domoic acid and saxitoxin in live sea otters (White et al. 2013). The first confirmed case of acute HAB toxicity in Washington was documented in May 2015 in a California sea lion Zalophus californianus (McCabe et al. 2016).

Given the presence of both toxins on the Washington coast, the overlapping range of the eastern distinct population segment (DPS) Steller sea lions Eumetopias jubatus and California sea lions suggests that both species could be exposed to algal toxins through contaminated prey. Steller sea lions from all demographic groups live and forage on the Washington coast year-round, while primarily male California sea lions migrate into Washington waters seasonally (NMFS 2013, Gearin et al. 2017). While the US population of California sea lions is estimated at a healthy 300000 individuals (Gearin et al. 2017), the Steller sea lion experienced an $80 \%$ reduction in abundance from the 1970s through the 1990s in US waters (Miller et al. 2005). This reduction was driven by declines in the western DPS (Gulf of Alaska through Russia; west of $144^{\circ} \mathrm{W}$ ), which is currently listed as endangered under the US Endangered Species Act while the eastern DPS was recently delisted (NMFS 2013). Although no mortalities related to algal toxins have been reported in Steller sea lions, monitoring the threat of biotoxins is a priority in the recovery plan of the western DPS and post-delisting monitoring of the eastern DPS (NMFS 2013).

Sea lions change their diet based on seasonally and locally abundant prey and may migrate in response to seasonal prey fluctuations (Sigler et al. 2009). The diets of both Steller and California sea lions, composed of a variety of bony and cartilaginous fishes and cephalopods, are often dominated by only a few species (Sinclair \& Zeppelin 2002, Orr et al. 2011), although as many as 25 different prey items have been found in a single scat (Riemer et al. 2011). Domoic acid and PSTs have been detected in both benthic and pelagic fish (Lefebvre et al. 2002, Vigilant \& Silver 2007, Jester et al. 2009, Jensen et al. 2015), suggesting that while a more diverse diet could lessen the effects of acute toxicity experienced by ingesting a single contaminated prey species, generalist predators are at risk of exposure from multiple prey items.

In this study, we assessed the year-round exposure of free-ranging Steller and California sea lions species in Washington State to domoic acid and saxitoxin by comparing the toxin concentrations measured in feces to the prey remains in the scat and to toxin concentrations measured in nearshore bivalves. The goals of this study were to (1) determine year-round baseline levels of HAB toxins in the feces of both sea lion species and to identify factors associated with toxin exposure, including season, year, and haulout location; (2) determine if there was a difference in diet between sea lions with and without measureable levels of toxins and whether particular prey items were more associated with toxin exposure; and (3) compare the presence and concentration of toxins in the scat to that in nearshore bivalves to determine how toxin levels in nearshore bivalves predicted toxin exposure of top predators.

\section{MATERIALS AND METHODS}

\section{Study area and sample collection}

Steller and California sea lion scats were collected at haulout sites on the northern Washington coast (Fig. 1). Scats were collected seasonally from March 2011 through February 2013. Seasons were defined as spring: March-May; summer: June-August; fall: September-November; and winter: DecemberFebruary. Scats were only collected from sites where $\geq 95 \%$ of sea lions at the collection site belonged to a single species. Feces were scooped into individual plastic Whirl-Pak ${ }^{\mathrm{TM}}$ bags for storage. Because domoic acid and saxitoxin are water-soluble, only $<48 \mathrm{~h}$ old scats (moist, not weathered or dried out) were analyzed. For collection and analysis, we grouped haulouts in close proximity to each other (between 0.5$1.3 \mathrm{~km}$ ) into 3 complexes: Tatoosh Island, Bodelteh Islands, and Carroll Island/Sea Lion Rock (Fig. 1).

\section{Toxin analysis}

We collected approximately $4 \mathrm{~g}$ of fecal material from each scat, stored each in a $15 \mathrm{ml}$ centrifuge tube, and froze all samples at $-20^{\circ} \mathrm{C}$. To ensure that no prey remains were lost during subsampling, the $4 \mathrm{~g}$ of fresh scat were pushed through either a nylon, fine mesh, paint strainer bag $(0.25 \mathrm{~mm})$, or through a $0.5 \mathrm{~mm}$ brass sieve to be collected for toxin analysis. 


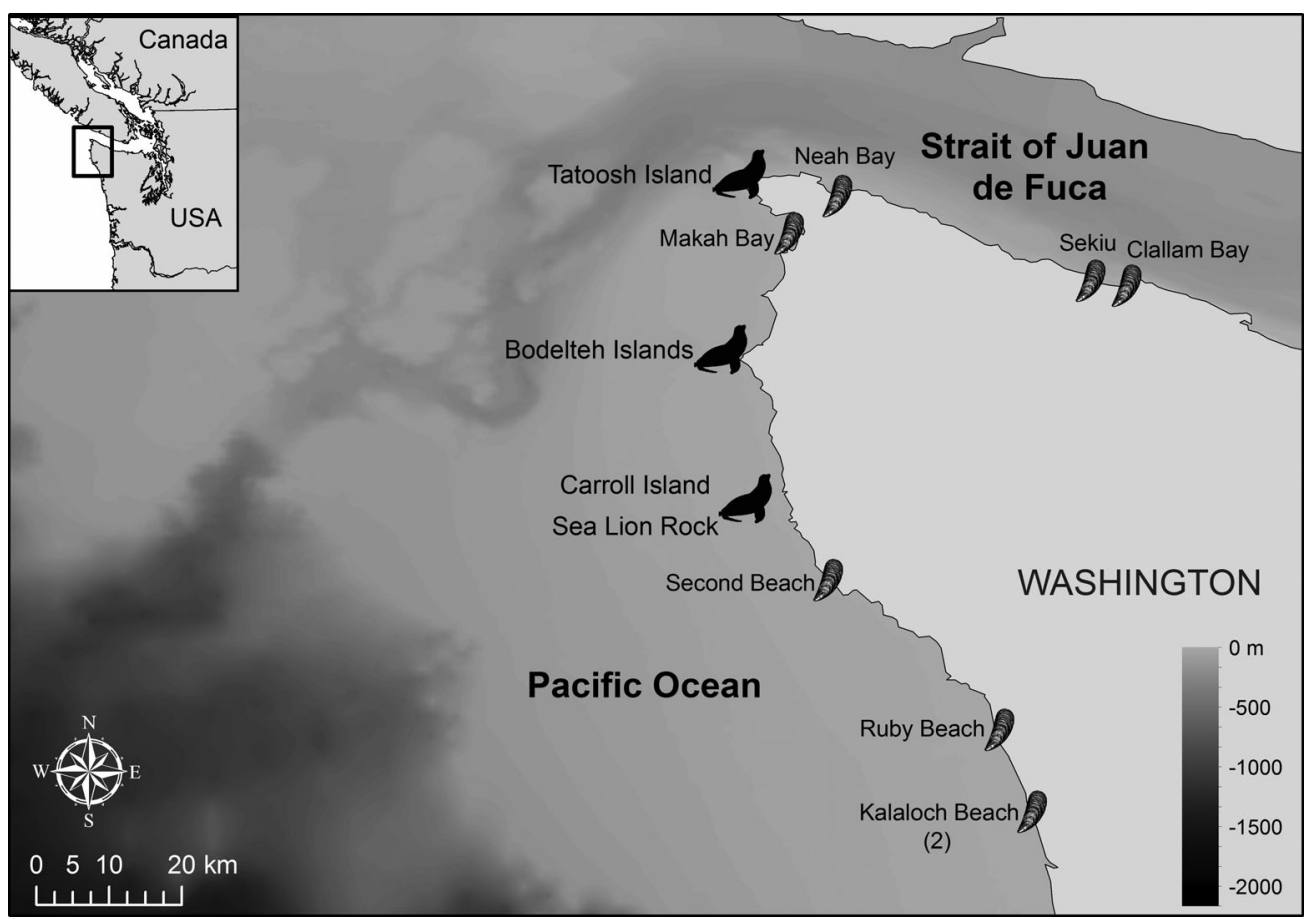

Fig. 1. Sample locations of bivalves and sea lion scat along the western Strait of Juan de Fuca and northwest Washington coast, USA. Parentheses refer to sites having more than 1 sample location. Bathymetry is shaded according to depth (m)

When scats were small and had insufficient material for analyzing both toxins (i.e. $<4 \mathrm{~g}$ ), we prioritized the analysis of domoic acid because the toxin has caused strandings and mortalities of sea lions on the US West Coast (Fire \&Van Dolah 2012).

Scat subsamples were analyzed using direct competitive enzyme-linked immunosorbent assays (ELISA) following methods described by Lefebvre et al. (2016). Domoic acid was analyzed using ASP direct cELISA kits (Biosense Laboratories). Saxitoxin was analyzed using saxitoxin (paralytic shellfish poisoning [PSP]) ELISA kits (Abraxis). The lower quantification limits were $3 \mathrm{ng} \mathrm{g}^{-1}$ for saxitoxin and $4 \mathrm{ng} \mathrm{g}^{-1}$ for domoic acid. Due to a sample-processing error, the sample with the highest concentration of domoic acid measured (672.2 $\mathrm{ng} \mathrm{g}^{-1}$ detected in a California sea lion scat) was erroneously processed twice and recorded with 2 different identifications. Because we were unable to identify the sample, it was discarded from statistical analyses, but was included in the range of concentrations detected.

ELISA analysis of domoic acid in marine mammal feces and fluids has been validated by comparison to traditional methodologies including high-performance liquid chromatography (HPLC) and liquid chromatography tandem mass spectrometry (LC-MS/MS) (Lefebvre et al. 2010, Frame \& Lefebvre 2013). ELISA results from marine mammal tissues generally agree with those of HPLC and LC-MS/MS (Frame \& Lefebvre 2013). ELISA is also able to detect domoic acid at concentrations below the quantification limit for these traditional methods, particularly in marine mammal feces (Lefebvre et al. 2010, Frame \& Lefebvre 2013).

Previous studies of saxitoxin in marine mammal feces and fluids have also used the Abraxis Saxitoxin ELISA (Lefebvre et al. 2016). The Abraxis ELISA detects saxitoxin $100 \%$, but has limited cross-reactivity $(<30 \%)$ of other PST congeners as specified by the manufacturer. We report our results as saxitoxin only because we cannot detect the presence or total concentration of all PST congeners. Other toxic congers, such as the gonyautoxins, may be more prevalent in the environment than saxitoxin itself, and this limited cross-reactivity could underestimate the actual toxicity of the sample (Turner et al. 2014). While HPLC or LC-MS/MS would provide a more extensive toxin profile and the concentrations of other congeners, these analyses for PSTs are costly, time-consuming, and limited to the congeners for which commercial standards are available (Costa et al. 2009, Humpage et al. 2010). In seawater and shellfish, the Abraxis ELISA detects saxitoxin at lower concentrations compared to traditional methods such as HPLC (Costa et al. 2009). 


\section{Analysis of food habits}

The remaining fecal material was processed for analysis of food habits. For the majority of samples, we used a washing machine to clean the fresh fecal material from the prey remains (Orr et al. 2003). Samples with gravel were washed by hand through nested sieves of 2, 1 , and $0.5 \mathrm{~mm}$. Prey remains were identified to the lowest taxonomic group possible using a comparative reference collection of fish from the northeast Pacific Ocean (Riemer et al. 2011). Prey remains included bones (e.g. otoliths, vertebrae, teeth, gill rakers, etc.), cartilaginous structures, and cephalopod beaks. Salmonids (Oncorhynchus spp.) were identified by size and grouped as 'juvenile' (smolts) and 'non-juvenile' (all other age classes). Salmonid bones were classified as juveniles based on time of year and juvenile salmon growth rates in the study area (Duffy \& Beauchamp 2011) and comparison to reference collections of juvenile and non-juvenile salmonid bones. Remains that could not be identified to a more specific taxonomic group were recorded as unidentified bony fish (class Osteichthyes) or unidentified cartilaginous fish (subclass Elasmobranchii). Prey items were recorded as present/absent for each sample and converted to percent frequency of occurrence (FO) in sea lion diet, where FO of a particular taxon is equal to the number of scats having that taxon divided by the total number of scats with any identifiable prey.

\section{Bivalve samples}

Biotoxin results measured in nearshore bivalves from January 2011 through March 2013 were provided by the Washington Department of Health (WDOH) Biotoxin Monitoring Program. PSTs were detected using the standardized mouse bioassay, with a detection limit of approximately $40 \mu \mathrm{g} 100$ $\mathrm{g}^{-1}$ shellfish (400 $\mathrm{ng} \mathrm{g}^{-1}$ ) (AOAC 1965, APHA 1970). Domoic acid was detected using HPLC, with a detection limit of approximately $0.5 \mathrm{ppm}$ (500 ng $\mathrm{g}^{-1}$ ) (Quilliam et al. 1995). Bivalves were collected from 8 locations in the western Strait of Juan de Fuca and northern Washington coast (Fig. 1). Contributors to this dataset included the Makah and Quileute Tribes and the Washington Department of Fish and Wildlife, who perform monitoring for subsistence and recreational harvest. Although a variety of bivalve species are collected for monitoring, only the 2 most common species are included here:
California mussel Mytilus californianus and Pacific razor clam Siliqua patula. California mussels were the dominant species collected at all sites except for 2 locations at Kalaloch Beach (Fig. 1), where razor clams were dominant.

Nearshore bivalve toxin concentrations were plotted against the concentrations in sea lion scats to examine the relationship between presence and concentration of toxin in bivalves to that in the scats. For both toxins, samples reported by WDOH as 'not detected' are reported here as '0.' Due to method-detection limits and reporting criteria, WDOH reports concentrations of saxitoxin considered below the quantification limit as $<380 \mathrm{ng} \mathrm{g}^{-1}$, which we plotted as $380 \mathrm{ng} \mathrm{g}^{-1}$. Similarly, for domoic acid, WDOH reports concentrations below $1000 \mathrm{ng} \mathrm{g}^{-1}$ as $<1000 \mathrm{ng} \mathrm{g}^{-1}$. We substituted reported values of $<1000 \mathrm{ng} \mathrm{g}^{-1}$ with $500 \mathrm{ng} \mathrm{g}^{-1}$ in our plots to differentiate between a true measured concentration of $1000 \mathrm{ng} \mathrm{g}^{-1}$ and $<1000 \mathrm{ng} \mathrm{g}^{-1}$ because the true concentration between the detection limit (500 $\mathrm{ng} \mathrm{g}^{-1}$ ) and reporting limit (1000 $\mathrm{ng} \mathrm{g}^{-1}$ ) was not available.

\section{Statistical analysis}

We used binary logistic regression models and Akaike's information criterion (AIC) in the statistical program R (R Core Team 2015) to examine which factors best predicted the presence or absence of toxin in sea lion scats. The dependent variable was the presence/absence of either domoic acid or saxitoxin in the scat. All explanatory variables were modeled as categorical and included haulout complex, season, and year, which was defined as 'Year 1,' representing samples from March 2011 through February 2012, and 'Year 2,' representing samples from March 2012 through February 2013.

For analyzing the influence of diet on toxin exposure, we compared the prey remains in the scat to the presence/absence or categorical level of toxin. We included only prey taxa that had a total FO of $\geq 5 \%$ averaged over all seasons and discarded scats containing unidentified bony or cartilaginous fish only. Prey taxa were included at the lowest taxonomic classification identified, both individual species and unidentified species grouped by a higher taxonomic level. For both toxins, categorical levels were defined as 'no' representing samples below the detection limit, 'low' between 0 and $20 \mathrm{ng} \mathrm{g}^{-1}$, 'med' between $>20$ and $50 \mathrm{ng} \mathrm{g}^{-1}$, and 'high' representing concentrations $>50 \mathrm{ng} \mathrm{g}^{-1}$. 
Table 1. Number of scats collected per season at each haulout complex from Steller sea lions Eumetopias jubatus and California sea lions Zalophus californianus and the total number of scats analyzed for domoic acid (DA) and saxitoxin (STX)

\begin{tabular}{|c|c|c|c|c|c|}
\hline Species & Season/year & $\begin{array}{l}\text { Tatoosh Island } \\
\text { complex }\end{array}$ & $\begin{array}{l}\text { Bodelteh Island } \\
\text { complex }\end{array}$ & $\begin{array}{c}\text { Carroll Island/ } \\
\text { Sea Lion Rock complex }\end{array}$ & $\begin{array}{l}\text { Total } \\
\text { scats }\end{array}$ \\
\hline \multirow[t]{10}{*}{ E. jubatus } & Spring 2011 & 36 & - & 14 & 50 \\
\hline & Summer 2011 & - & - & 46 & 46 \\
\hline & Fall 2011 & 11 & - & 39 & 50 \\
\hline & Winter 2011/2012 & 37 & - & - & 37 \\
\hline & Spring 2012 & 24 & 8 & 18 & 50 \\
\hline & Summer 2012 & 8 & 4 & 38 & 50 \\
\hline & Fall 2012 & 26 & - & 29 & 55 \\
\hline & Winter 2012/2013 & 45 & - & - & 45 \\
\hline & Total DA & 187 & 12 & 184 & 383 \\
\hline & Total STX & 185 & 12 & 176 & 373 \\
\hline \multirow[t]{6}{*}{ Z. californianus } & Spring 2011 & - & 20 & - & 20 \\
\hline & Fall 2011 & - & 45 & - & 45 \\
\hline & Summer 2012 & - & 19 & - & 19 \\
\hline & Fall 2012 & - & 41 & - & 41 \\
\hline & Total DA & - & 125 & - & 125 \\
\hline & Total STX & - & 121 & - & 121 \\
\hline
\end{tabular}

Designation of toxin levels was based on natural breaks in the concentrations measured in scats and is not intended to be indicative of toxicological effects.

We used nonmetric multi-dimensional scaling (NMDS) in the Community Ecology Package (vegan) of R (Oksanen et al. 2017) to investigate the influence of overall diet on toxin exposure and used Pearson's chi-squared and Fisher's exact tests to compare the presence of individual prey items to presence/absence or categorical toxin levels. For the 2 sea lion species, we ran NMDS for each toxin separately using the metaMDS function, which can handle zero distance where 2 points are identical (Oksanen et al. 2017), and a binary Jaccard distance matrix. For analysis of individual prey items, we used chi-squared tests when expected values of at least $80 \%$ of the cells were $\geq 5$ and Fisher's exact tests when expected values were $<5$ (McHugh 2013). Standardized residuals from chi-squared tests were evaluated to determine whether toxin was significantly higher or lower than expected values based on presence or absence of each prey item where residual values $>|1.96|$ were considered significant at $\mathrm{p}<0.05$ (Agresti 2007). For Fisher's exact tests, we used odds ratios and confidence intervals to evaluate positive or negative relationships of significant $\mathrm{p}$-values and performed post hoc testing using Bonferroni-corrected p-values where the corrected alpha was calculated as 0.05 divided by the number of pairwise comparisons.

\section{RESULTS}

\section{Toxin detection}

We collected a total of 383 scats from Steller sea lions and 125 scats from California sea lions (Table 1). Of the 508 total scats, 14 samples did not have sufficient fecal material to analyze both toxins and were only analyzed for domoic acid (Table 1). Saxitoxin was detected in $45 \%$ of all scat samples analyzed and domoic acid was detected in $17 \%$ of samples analyzed. The toxins were detected concurrently in 26 scats from Steller sea lions and 6 scats from California sea lions. The highest concentrations of saxitoxin in both sea lion species were detected in Year 1 (Fig. 2A) and in spring (Fig. 2C), while domoic acid was higher in Year 2 for both species (Fig. 2B) and in summer for Steller sea lions and fall for California sea lions (Fig. 2D). In Steller sea lions, the highest concentrations of saxitoxin were from the Tatoosh Island complex (Fig. 2E), while the highest concentrations of domoic acid were from the Carroll Island/Sea Lion Rock complex (Fig. 2F).

\section{Toxin prevalence by season, year, and location}

Logistic regression analysis identified several explanatory models for the presence of toxins in Steller sea lions, but for California sea lions, the interceptonly model had the lowest AIC for both domoic acid 

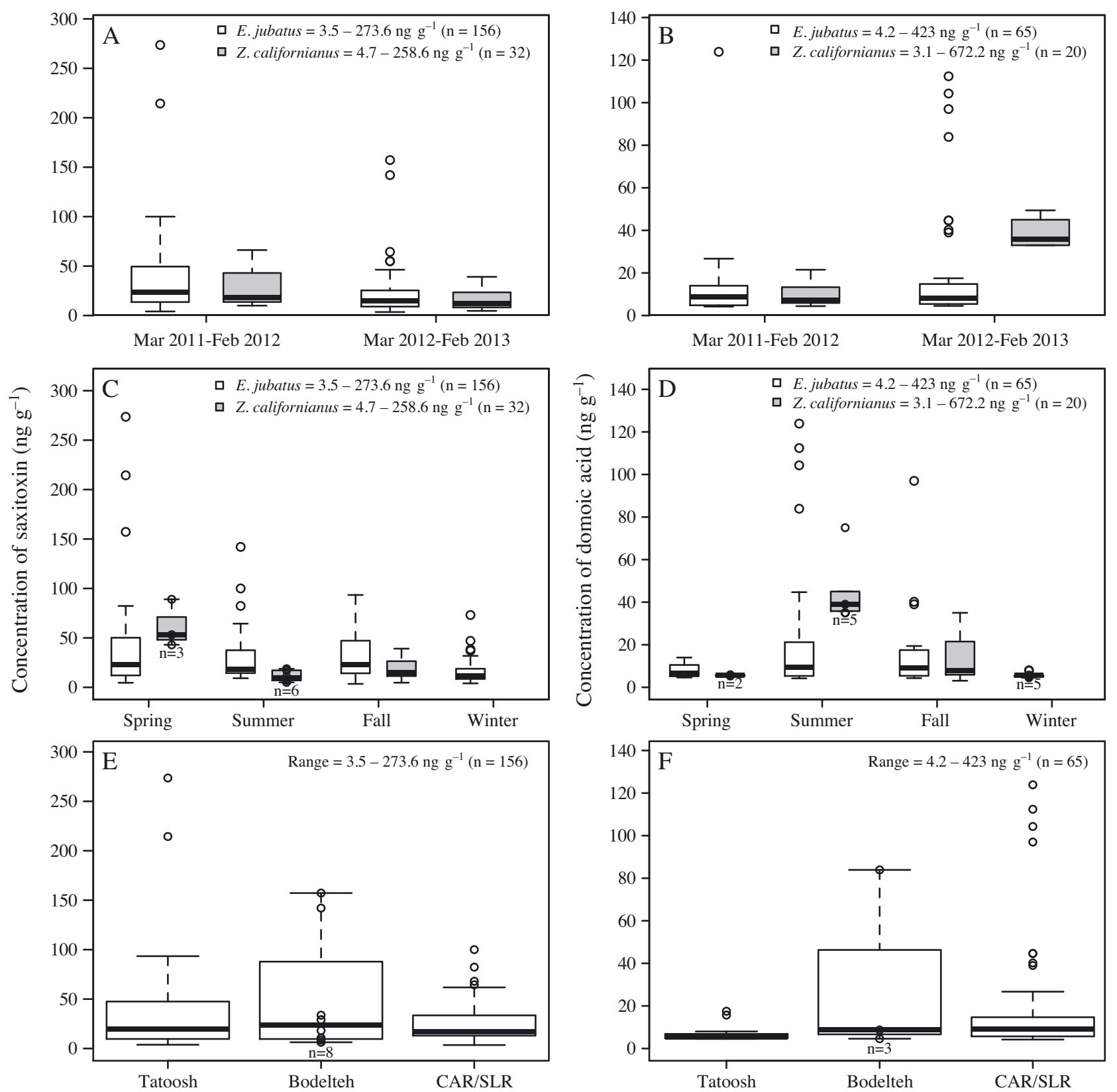

Fig. 2. Concentrations of saxitoxin (left column) and domoic acid (right column) above detection limit in Steller sea lion Eumetopias jubatus (white) and California sea lion Zalophus californianus (gray) scats by $(\mathrm{A}, \mathrm{B})$ year, $(\mathrm{C}, \mathrm{D})$ season, and (E,F) haulout complex (E. jubatus only). Boxplots display the median (bold line), the first quartile (below the median), third quartile (above the median), and whiskers representing range. Points above the whiskers represent outliers; points inside the boxes and whiskers represent the actual concentrations measured and are presented in the case of sample sizes $<10$, as denoted by $\mathrm{n}$ values. Maximum domoic acid concentrations (423 $\mathrm{ng} \mathrm{g}^{-1}$, summer of Year 2; $672.2 \mathrm{ng} \mathrm{g}^{-1}$, fall of Year 2) are not displayed. CAR/SLR: Carroll Island/Sea Lion Rock

and saxitoxin. In Steller sea lions, the most parsimonious model for predicting the presence of saxitoxin when considering season and year only was the full model including season, year, and their interaction (Table 2, Fig. 3A). When also considering haulout complex, the most parsimonious model included com- plex, year, and their interaction (Table 3, Fig. 3B). For domoic acid, the most parsimonious model when considering season and year included the additive effect of season and year (Table 2, Fig. 3C), but when also considering haulout complex, included haulout complex only (Table 3, Fig. 3D). 
Table 2. Presence/absence of saxitoxin ( $\mathrm{n}=373$ scats) and domoic acid ( $\mathrm{n}=383$ scats) in Steller sea lion Eumetopias jubatus scats compared to season and year. For simplicity, models displaying an interaction $(\mathrm{a} \times \mathrm{b})$ signify that the full model was tested including the main effects and their interaction $(a+b+a \times b)$. The most parsimonious models (with lowest Akaike's information criterion, AIC) are shown in bold

\begin{tabular}{|lcclllr|}
\hline \multirow{2}{*}{ Variable } & \multicolumn{2}{c}{ Saxitoxin } & Variable & \multicolumn{2}{c|}{ Domoic acid } \\
& df & AIC & & df & AIC \\
\hline Intercept only & 1 & 509.07 & & Intercept only & 1 & 350.86 \\
Season & 4 & 511.67 & & Season & 4 & 336.77 \\
Year & 2 & 484.84 & & Year & 2 & 346.66 \\
Season+Year & 5 & 488.15 & & Season+Year & $\mathbf{5}$ & $\mathbf{3 3 1 . 9 9}$ \\
Season×Year & $\mathbf{8}$ & $\mathbf{4 8 2 . 4 6}$ & & Season×Year & 8 & 333.87 \\
& & & & & & \\
\hline
\end{tabular}

\section{Sea lion diet}

A total of 39 prey taxa (lowest taxonomic group) were identified in Steller sea lion scats (see Table S1 in the Supplement at www.int-res.com/articles/suppl/ m583p243_supp.pdf) and 30 prey taxa were identified in California sea lion scats (Table S2). Eleven scats from Steller sea lions and 6 scats from California sea lions contained no identifiable prey remains (unidentified bony or cartilaginous fish) and were removed from the diet analyses. For Steller sea lions, the most common prey items (>20\% FO in the diet) were clupeids (family Clupeidae, 56\%), salmonids (Oncorhynchus spp., 40\%), skates (family Rajidae, $40 \%$ ), rockfish (Sebastes spp., 36\%), Pacific spiny dogfish Squalus acanthias (28\%), and flatfish (order Pleuronectiformes, $21 \%$ ) (Table S1). For California sea lions, the most common prey items were clupeids (79\%), salmonids (38\%), Pacific hake Merluccius productus (32\%), and dogfish (30\%) (Table S2). The 2 sea lion species had several major differences in diet including skate consumption $(40 \%$ in Steller compared to $5 \%$ in California sea lions), flatfishes (21\% in Steller compared to $8 \%$ in California sea lions), and codfishes (family Gadidae) (18\% in Steller and $6 \%$ in California sea lions).

Sea lion diet varied by season, collection year, and haulout complex. For Steller sea lions, consumption of skates, rockfish, and Pacific herring Clupea pallasii was noticeably higher in spring of Year $2(68,60$, and $22 \%$ FO, respectively) compared to Year $1(34,30$, and $6 \%$ ), whereas dogfish was more common in spring of Year 1 (42\%) compared to Year 2 (22\%). Walleye pollock Gadus chalcogramma had a spike in occurrence in spring of Year 1 (30\% FO), but was present in < $\%$. of samples in all other seasons of both collection years. Northern anchovy Engraulis mordax was present in spring, summer, and fall of Year $1(14,13$, and 18\%
FO), but was virtually absent in Year $2(0,2$, and $4 \%$ ). Juvenile salmonids and Pacific sand lance Ammodytes hexapterus were present in winter of Year 2 (38 and 13\%, respectively), but absent in Year 1 (0 and $1 \%$ ). For California sea lions, hake consumption dropped dramatically from fall of Year 1 $(53 \%)$ to Year $2(8 \%)$. For Steller sea lions, salmonids and codfishes were more common in samples from Tatoosh Island (57 and $29 \%$, respectively) compared to Carroll Island/Sea Lion Rock (22 and 12\%), whereas the reverse was true for flatfishes $(40 \%$ at Carroll Island/Sea Lion Rock compared to $7 \%$ at Tatoosh).

\section{Diet influences on toxin prevalence}

There were no convergent solutions using NMDS for analyzing diet of either Steller or California sea lions to look for differences in toxin presence. Chisquared and Fisher's exact analyses identified several prey items significantly associated with the presence or concentration level of toxins found in the scat (Tables 4-6). In Steller sea lion scats, saxitoxin presence was significantly higher than expected when American shad Alosa sapidissima and walleye pollock were present in the scat (Table 4). Saxitoxin was detected in every scat with pollock prey remains ( $\mathrm{n}=$ 18 scats), and scats with pollock were significantly more likely to have medium and high levels of saxitoxin compared to low concentrations (Table 6), including 2 of the highest concentrations measured (214.4 and 273.6 $\mathrm{ng} \mathrm{g}^{-1}$ ). Domoic acid presence was significantly higher than expected when Pacific sardine Sardinops sagax and starry flounder Platichthys stellatus were present (Table 4). Scats with sardine were significantly more likely to have high concentrations of domoic acid (Table 6). In California sea lions, scats with anchovy were about 5 times more likely to have domoic acid compared to those without anchovy (Table 4).

\section{Comparison to nearshore bivalves}

Between January 2011 and March 2013, PSTs were detected in concentrations $>380 \mathrm{ng} \mathrm{g}^{-1}$ in 58 samples of California mussels Mytilus californianus and 4 samples of razor clams Siliqua patula (Fig. 4). Domoic acid was almost exclusively detected in razor clams (Fig. 5). PST concentrations peaked in the summer of 

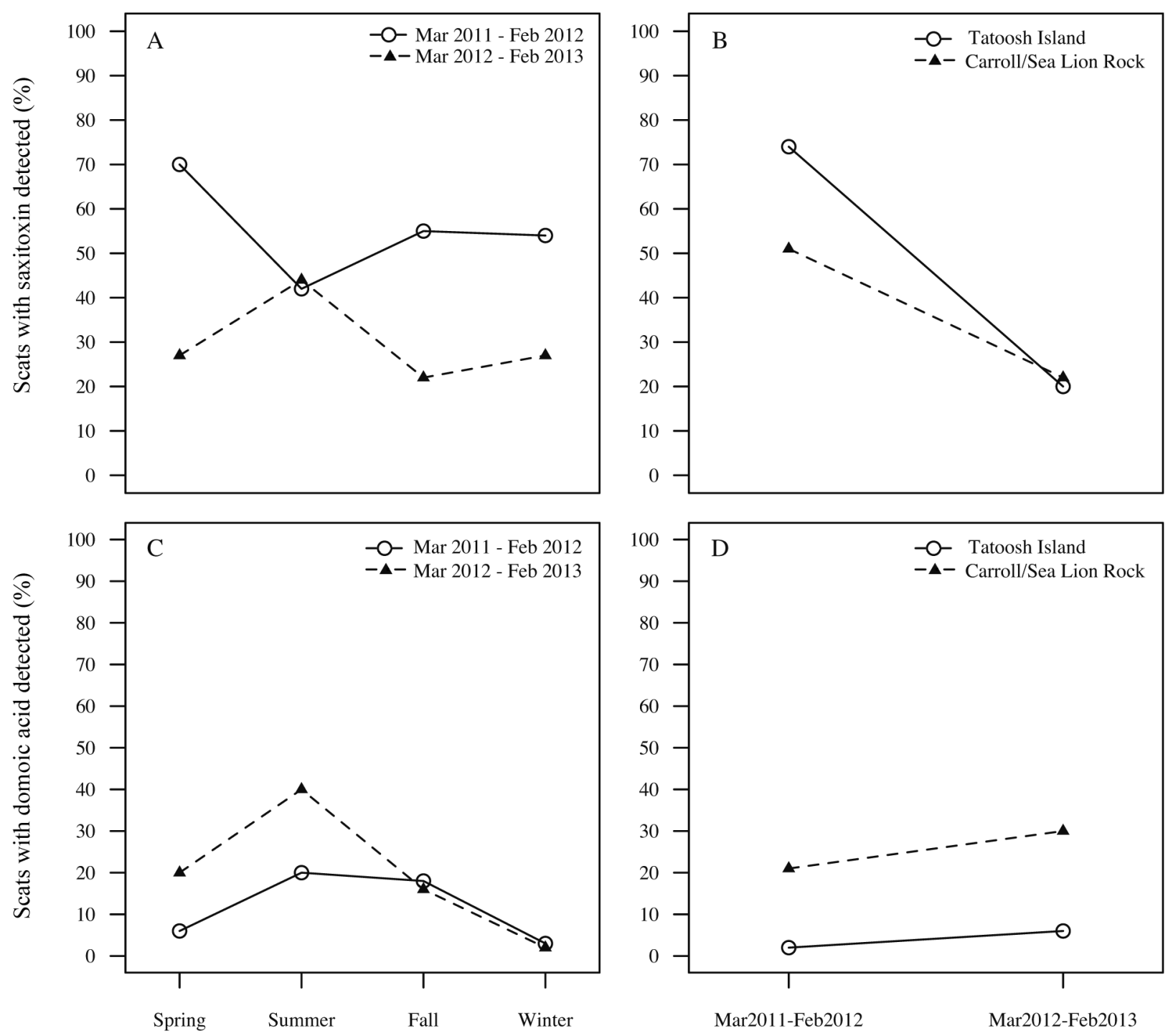

Fig. 3. Percent of scats with $(A, B)$ saxitoxin and $(C, D)$ domoic acid detected for Steller sea lions Eumetopias jubatus $(A, C)$ by season and year and $(\mathrm{B}, \mathrm{D})$ by year and haulout complex (see Fig. 1)

2011 and the summer/fall of 2012 (Fig. 4). Domoic acid peaked in the fall of both years, detected in concentrations above $1000 \mathrm{ng} \mathrm{g}^{-1}$ in 24 razor clam samples and at a concentration $<1000 \mathrm{ng} \mathrm{g}^{-1}$ in a single sample of California mussel (Fig. 5). In periods of high PST concentrations in bivalves (e.g. July and August 2012) the majority of sea lion scats did not have detectable levels of saxitoxin (Fig. 4). Conversely, time periods when most sea lion scats had detectable levels of saxitoxins (e.g. April and May 2011) bivalves had no to very low $\left(<380 \mathrm{ng} \mathrm{g}^{-1}\right)$ concentrations of PSTs (Fig. 4). In several time periods (e.g. February and March 2012), sea lions had detectable levels of saxitoxin while no toxins were detected in nearshore bivalves (Fig. 4). Domoic acid in sea lion scats appeared to peak slightly before peaks observed in bivalves in the fall of both years (Fig. 5).

\section{DISCUSSION}

\section{Toxin retention in the food web}

This is the first study to systematically document that West Coast marine mammals are exposed to domoic acid and saxitoxin year-round. Although Steller sea lions and California sea lions on the outer coast of Washington were more often exposed to saxitoxin than to domoic acid, both toxins were detected in scats in every season and month of the 
Table 3. Presence/absence of saxitoxin ( $\mathrm{n}=190$ scats) and domoic acid $(\mathrm{n}=197$ scats) in Steller sea lion Eumetopias jubatus scats by season, year, and haulout complex. Scats were not collected from all haulout complexes in all seasons; these models include scats from 2 seasons, spring and fall, and 2 haulout complexes, Tatoosh Island and Carroll/Sea Lion Rock. For simplicity, models displaying an interaction $(\mathrm{a} \times \mathrm{b})$ represent the full model including the main effects and their interaction $(a+b+a \times b)$. The most parsimonious models (with lowest Akaike's Information Criterion, AIC) are shown in bold

\begin{tabular}{|c|c|c|c|c|c|}
\hline \multirow{3}{*}{$\begin{array}{l}\text { Variable } \\
\text { Intercept only }\end{array}$} & \multirow{2}{*}{\multicolumn{2}{|c|}{$\begin{array}{l}\text { Saxitoxin } \\
\text { df AIC }\end{array}$}} & \multirow[t]{2}{*}{ Variable } & \multicolumn{2}{|c|}{ Domoic acid } \\
\hline & & & & df & $\mathrm{AIC}$ \\
\hline & 1 & 259.98 & Intercept only & 1 & 166.63 \\
\hline Season & 2 & 259.66 & Season & 2 & 167.56 \\
\hline Complex & 2 & 260.09 & Complex & 2 & 149.81 \\
\hline Year & 2 & 226.37 & Year & 2 & 167.43 \\
\hline Season+Complex & 3 & 260.69 & Season+Complex & 3 & 151.75 \\
\hline Season+Year & 3 & 227.36 & Season+Year & 3 & 168.50 \\
\hline Complex+Year & 3 & 225.62 & Complex+Year & 3 & 150.00 \\
\hline Season $\times$ Complex & 4 & 262.69 & Season $\times$ Complex & 4 & 153.32 \\
\hline Season $\times$ Year & 4 & 227.90 & Season $\times$ Year & 4 & 167.76 \\
\hline Complex $\times$ Year & 4 & 224.75 & Complex $\times$ Year & 4 & 151.76 \\
\hline Season+Complex+Year & 4 & 227.36 & Season+Complex+Year & 4 & 151.97 \\
\hline Season $\times$ Complex + Year & 5 & 228.02 & Season $\times$ Complex + Year & 5 & 153.77 \\
\hline Season+Complex $\times$ Year & 5 & 226.71 & Season+Complex $\times$ Year & 5 & 153.70 \\
\hline Season $\times$ Year+Complex & 5 & 228.43 & Season $\times$ Complex + Site & 5 & 153.12 \\
\hline Season $\times$ Complex $\times$ Year & 8 & 226.68 & Season $\times$ Complex $\times$ Year & 8 & 157.29 \\
\hline
\end{tabular}

year. This finding suggests that both saxitoxin and domoic acid were either retained in the food web for long periods after blooms (Twiner et al. 2011, Jensen et al. 2015) or transferred from sediments or dormant cysts back into the marine food web (Vigilant \& Silver 2007).
Given past studies on domoic acid and PST retention in fish and mammals, it is unlikely that either the prey or the sea lions themselves were retaining the toxins in their tissues for long periods after blooms. Domoic acid administered to northern anchovy Engraulis mordax remained in some tissues for up to $1 \mathrm{wk}$ (Lefebvre et al. 2001), and PSTs (specifically N-sulfocarbamoyl-11-hydroxysulfate) were retained in fish as long as $2 \mathrm{wk}$ after exposure (Kwong et al. 2006). Conversely, some species of cephalopod appear to hold domoic acid for several months after algal blooms (Lopes et al. 2013). In the present study, however, only 2 winter scat samples containing cephalopod remains also contained toxin. Although brevetoxin, produced by the dinoflagellate Karenia brevis, was detected in fish tissues for $1 \mathrm{yr}$ following active algal blooms (Twiner et al. 2011), the potential for long-term retention of domoic acid and saxitoxin in West Coast fishes remains unclear. Clearance rates of domoic acid and PSTs have not been studied directly in sea lions, but in other mammal species, clearance of these toxins typically occurs within 24-48 h (Wittmaack et al. 2015), and it is most likely that toxins in the scat represent the sea lions' most recent feeding events.

Table 4. Significant Pearson's chi-squared or Fisher's exact tests $(\mathrm{p}<0.05)$ for $2 \times 2$ contingency tables comparing presence/ absence of prey to presence/absence of toxin in sea lion scat. Chi-squared statistics $\left(\chi^{2}\right.$, representing $\left.\Sigma \chi_{i-j}^{2}\right)$ and p-values for each $2 \times 2$ table are presented. Pearson's residuals are shown for presence of prey item:presence of toxin, with residuals $>11.96$ | being significant (in bold). Fisher's exact tests are reported as a significant $p$-value $(<0.05)$ with odds ratio and $95 \%$ confidence intervals (CI)

\begin{tabular}{|c|c|c|c|}
\hline Toxin/species & $\chi^{2}$ & $\mathrm{p}$ & Presence prey:presence toxin \\
\hline \multicolumn{4}{|l|}{ Saxitoxin } \\
\hline \multicolumn{4}{|l|}{ Steller sea lion Eumetopias jubatus } \\
\hline Non-juvenile salmonid Oncorhynchus spp. & 6.77 & 0.010 & 1.66 \\
\hline Skates, family Rajidae & 9.54 & 0.002 & -1.89 \\
\hline American shad Alosa sapidissima & 5.93 & 0.015 & 1.99 \\
\hline Walleye pollock Gadus chalcogramma & 23.86 & $<0.001$ & 3.82 \\
\hline \multicolumn{4}{|l|}{ California sea lion Zalophus californianus } \\
\hline Non-juvenile salmonid Oncorhynchus spp. & 4.87 & 0.027 & 1.70 \\
\hline \multicolumn{4}{|l|}{ Domoic acid } \\
\hline \multicolumn{4}{|l|}{ Steller sea lion E. jubatus } \\
\hline Non-juvenile salmonid Oncorhynchus spp. & 4.84 & 0.028 & -1.71 \\
\hline Spiny dogfish Squalus acanthias & 4.71 & 0.030 & 1.79 \\
\hline Pacific sardine Sardinops sagax & 23.49 & $<0.001$ & 4.41 \\
\hline Starry flounder Platichthys stellatus & 8.89 & 0.003 & 2.79 \\
\hline \multicolumn{4}{|l|}{ California sea lion $Z$. californianus } \\
\hline Northern anchovy Engraulis mordax & - & Fisher's p: 0.011 & Odds $4.99, \mathrm{CI}: 1.24-19.44$ \\
\hline
\end{tabular}


Table 5. Significant Pearson's chi-squared tests $(\mathrm{p}<0.05)$ and $\mathrm{p}$-values for $2 \times 4$ contingency tables comparing presence/ absence of prey to levels of no, low $\left(<20 \mathrm{ng} \mathrm{g}^{-1}\right)$, medium $\left(20-50 \mathrm{ng} \mathrm{g}^{-1}\right)$, and high $\left(>50 \mathrm{ng} \mathrm{g}^{-1}\right)$ concentrations of toxin in Steller sea lion scat. Chi-squared statistics $\left(\chi^{2}\right.$, representing $\left.\Sigma \chi_{i-j}^{2}\right)$ and p-values for each $2 \times 4$ comparison are presented. Pearson's residuals are shown for presence of prey item:level of toxin, with residuals $>11.96$ | being significant (in bold)

\begin{tabular}{|c|c|c|c|c|c|c|}
\hline \multirow{2}{*}{ Toxin/species } & \multirow[t]{2}{*}{$\chi^{2}$} & \multirow[t]{2}{*}{$\mathrm{p}$} & \multicolumn{4}{|c|}{ Pearson's residual (presence prey: level of toxin) } \\
\hline & & & Presence:no & Presence:Low & Presence:Med & Presence:High \\
\hline \multicolumn{7}{|l|}{ Saxitoxin } \\
\hline \multicolumn{7}{|l|}{ Steller sea lion Eumetopias jubatus } \\
\hline Rockfish, family Sebastidae & 20.11 & $<0.001$ & -0.07 & 2.35 & -1.03 & -2.55 \\
\hline Non-juvenile salmonid Oncorhynchus spp. & 8.15 & 0.043 & -1.41 & 0.74 & 1.19 & 1.14 \\
\hline Skates, family Rajidae & 12.20 & 0.007 & 1.61 & -1.44 & -0.26 & -1.62 \\
\hline Spiny dogfish Squalus acanthias & 12.37 & 0.006 & -0.56 & -1.45 & 1.82 & 1.80 \\
\hline
\end{tabular}

An alternate explanation for the detection of domoic acid and saxitoxin in winter scats is the transfer of toxins from the benthos to the pelagic food web. After blooms, Pseudo-nitzschia cells and particulate domoic acid sink to the bottom where they accumulate in sediments or degrade and release domoic acid (Vigilant \& Silver 2007). Fish may then ingest domoic acid from feeding on benthic or epibenthic inverte-

Table 6. Significant Fisher's exact tests $(\mathrm{p}<0.05)$ for $2 \times 4$ contingency, comparing presence/absence of prey to levels of no, low $\left(<20\right.$ ng $\left.g^{-1}\right)$, medium $\left(20-50 \mathrm{ng} \mathrm{g}^{-1}\right)$, and high $\left(>50 \mathrm{ng} \mathrm{g}^{-1}\right)$ concentrations of toxin in the scat. Fisher's exact $\mathrm{p}$-values for the overall $2 \times 4$ contingency tables are presented. Post hoc testing of all pairwise comparisons used a Bonferroni-adjusted alpha value to assess significance, where alpha was calculated as 0.05 divided by the number of pairwise comparisons. Significant $2 \times 2$ pairwise comparisons of presence of prey items at each toxin concentration level (e.g. presence of fish when low toxin levels in scat compared to presence of fish when no toxins in scat $=$ Low:No) are presented by $\mathrm{p}$-values with odds ratio and $95 \%$ confidence interval $(\mathrm{CI})$; -: not significant $(\mathrm{p}>0.05)$. Bold values indicate significance after Bonferroni-adjustment. NA refers to cells where no comparison could be made due to the prey not being present in scats having that toxin level

\begin{tabular}{|c|c|c|c|c|c|c|c|}
\hline Toxin/species & Fisher's p & Low:No & Med:No & High:No & Med:Low & High:Low & High:Med \\
\hline \multicolumn{8}{|l|}{ Saxitoxin } \\
\hline \multicolumn{8}{|l|}{ Steller sea lion Eumetopias jubatus } \\
\hline American shad Alosa sapidissima & 0.025 & 0.040 & - & - & - & - & - \\
\hline Walleye pollock Gadus chalcogramma & $<0.001$ & NA & NA & NA & - & $\begin{array}{c}<\mathbf{0 . 0 0 1} \\
\text { (odds: } 10.23 \\
\text { CI: } 2.6-49.69 \text { ) }\end{array}$ & $\begin{array}{c}\mathbf{0 . 0 1 4} \\
\text { (odds: } 5.01 \\
\text { CI: } 1.24-24.8 \text { ) }\end{array}$ \\
\hline \multicolumn{8}{|l|}{ California sea lion Zalophus californianus } \\
\hline Northern anchovy Engraulis mordax & 0.040 & - & - & $\begin{array}{c}0.021 \\
\text { (odds: } 9.42 \\
\text { CI: } 1.08-83.02 \text { ) }\end{array}$ & ) & - & - \\
\hline Octopuses, order Octopoda & 0.044 & - & $\begin{array}{c}0.032 \\
\text { (odds: } 13.03, \\
\text { CI: } 0.866-155 \text { ) }\end{array}$ & NA & - & NA & NA \\
\hline \multicolumn{8}{|l|}{ Domoic acid } \\
\hline \multicolumn{8}{|l|}{ Steller sea lion E. jubatus } \\
\hline $\begin{array}{l}\text { Non-juvenile salmonid Oncorhynchus } \\
\text { spp. }\end{array}$ & 0.007 & $\begin{array}{c}\mathbf{0 . 0 0 5} \\
\text { (odds: } 0.366 \text {, } \\
\text { CI: } 0.16-0.77 \text { ) }\end{array}$ & - & - & - & $\begin{array}{c}0.023 \\
\text { (odds: } 0.120 \\
\text { CI: } 0.009-0.96 \text { ) }\end{array}$ & - \\
\hline Spiny dogfish Squalus acanthias & 0.002 & $\begin{array}{c}\mathbf{0 . 0 0 2} \\
\text { (odds: } 2.66 \\
\text { CI: } 1.41-5.02 \text { ) }\end{array}$ & NA & NA & NA & NA & NA \\
\hline Pacific sardine Sardinops sagax & $<0.001$ & $\begin{array}{c}\mathbf{0 . 0 0 1} \\
\text { (odds: } 4.00 \\
\text { CI: } 1.61-9.59 \text { ) }\end{array}$ & - & $\begin{array}{l}\quad<\mathbf{0 . 0 0 1} \\
\text { (odds: } 75.61 \\
\text { CI: } 7.9-3636 \text { ) }\end{array}$ & - & $\begin{array}{c}\mathbf{0 . 0 0 4} \\
\text { (odds: } 18.3 \\
\text { CI: } 1.8-939 \text { ) }\end{array}$ & - \\
\hline Starry flounder Platichthys stellatus & $<0.001$ & $\begin{array}{c}\mathbf{0 . 0 1 6} \\
\text { (odds: } 2.90 \\
\text { CI: } 1.15-6.87 \text { ) }\end{array}$ & $\begin{array}{c}\mathbf{0 . 0 0 4} \\
\text { (odds: } 18.8 \\
\text { CI: } 2.05-235 \text { ) }\end{array}$ & NA & - & NA & NA \\
\hline \multicolumn{8}{|l|}{ California sea lion $Z$. californianus } \\
\hline American shad A. sapidissima & 0.024 & - & - & NA & - & NA & NA \\
\hline Northern anchovy E. mordax & 0.006 & $\begin{array}{c}\mathbf{0 . 0 1 6} \\
\text { (odds: } 6.59 \\
\text { CI: } 1.17-33.62 \text { ) }\end{array}$ & - & NA & - & NA & NA \\
\hline
\end{tabular}


brates (Vigilant \& Silver 2007). Similarly, bottomresting Alexandrium cysts can be resuspended into the water column by wave action of winter storms (Butman et al. 2014). Winter toxicity in shellfish has been attributed to cysts, which can retain high concentrations of PSTs (Schwinghamer et al. 1994). Dinoflagellate cysts, however, are considered highly fossilizable and appear largely resistant to digestion by benthic invertebrates (Ichimi \& Montani 2001). The detection of saxitoxin in winter sea lion scats suggests that Alexandrium cysts are being digested at some stage in the food chain.

The exact pathways of winter toxin exposure to the sea lions remain unknown in this study. While domoic acid and PSTs have been detected in several benthic flatfish species (Vigilant \& Silver 2007, Jensen et al. 2015), consumption of flatfishes in this study dropped sharply in the winter. The most common prey items in winter scats containing saxitoxin were rockfish Sebastes spp. (22 of 31 scats) and nonjuvenile salmonids Oncorhynchus spp. (19 of 31 scats), while scats with domoic acid $(n=5)$ contained salmonids, skates (Rajidae family), Pacific spiny dogfish Squalus acanthias, and Pacific herring Clupea pallasii. Lefebvre et al. (2002) proposed that salmon and rockfish feeding on krill at the surface or at depth may transport domoic acid up the food chain. Because rockfish and salmon recovered in sea lion scats cannot be easily identified to species without the use of molecular analysis techniques (Tollit et al. 2009), it is not possible to confirm by which possible pathways these fish may have acquired and transferred the toxins up the food chain to the sea lions.

One surprising finding of this study is evidence that walleye pollock Gadus chalcogramma may be a vector of saxitoxin exposure in Steller sea lions, which could present a significant problem for the endangered western DPS sea lions that rely on this fish in
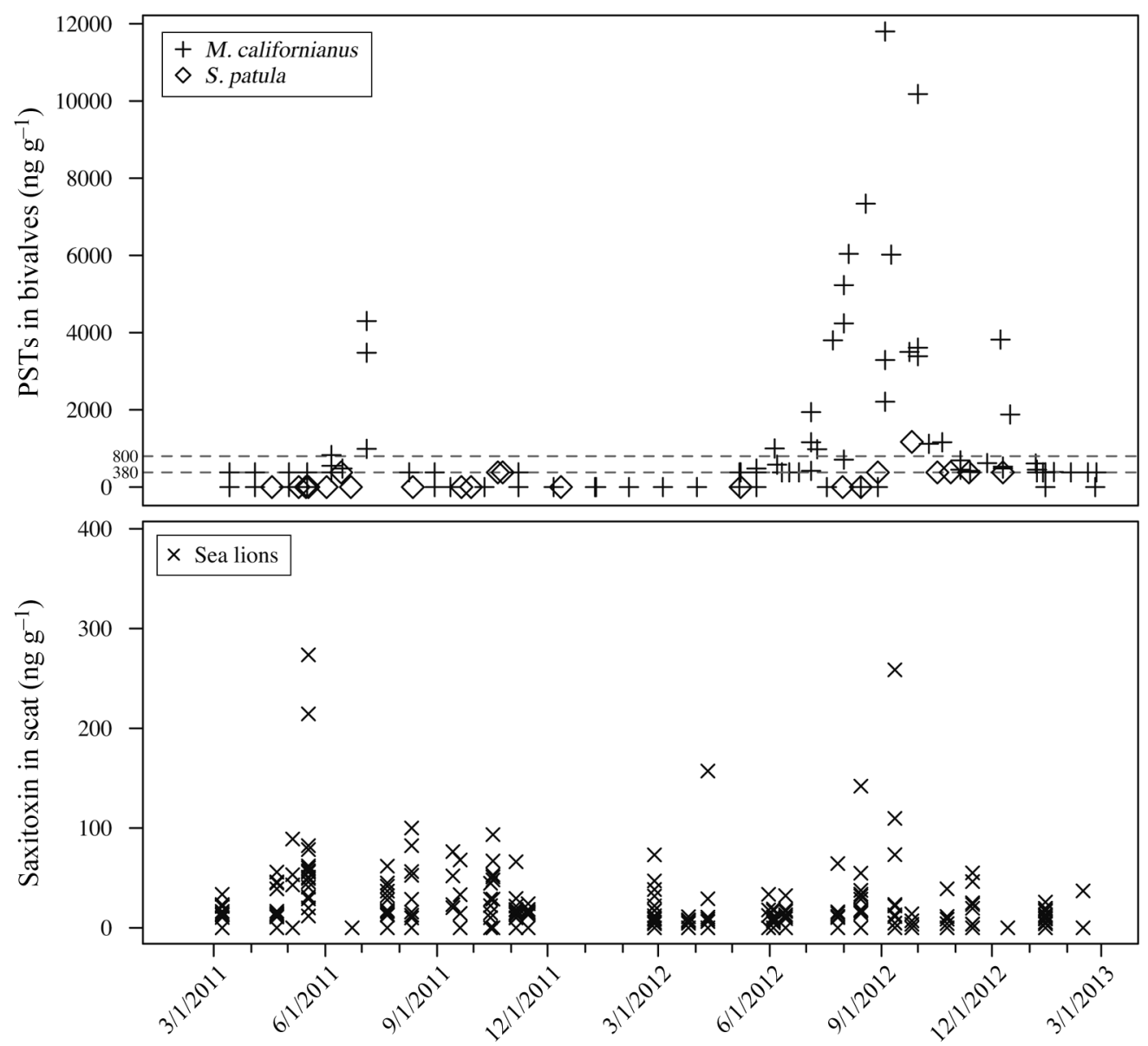

Fig. 4. Concentrations of paralytic shellfish toxins (PSTs) measured in California mussels Mytilus californianus and razor clams Siliqua patula, and saxitoxin measured in sea lions (Steller Eumetopias jubatus and California Zalophus californianus) between March 2011 and March 2013. The dashed lines indicate samples reported here as $380 \mathrm{ng} \mathrm{g}^{-1}$ that represent concentrations reported by the Washington Department of Health of $<380 \mathrm{ng} \mathrm{g}^{-1}$ and samples $>800 \mathrm{ng} \mathrm{g}^{-1}$ that represent concentrations above the human regulatory limit of $800 \mathrm{ng} \mathrm{g}^{-1}$ 

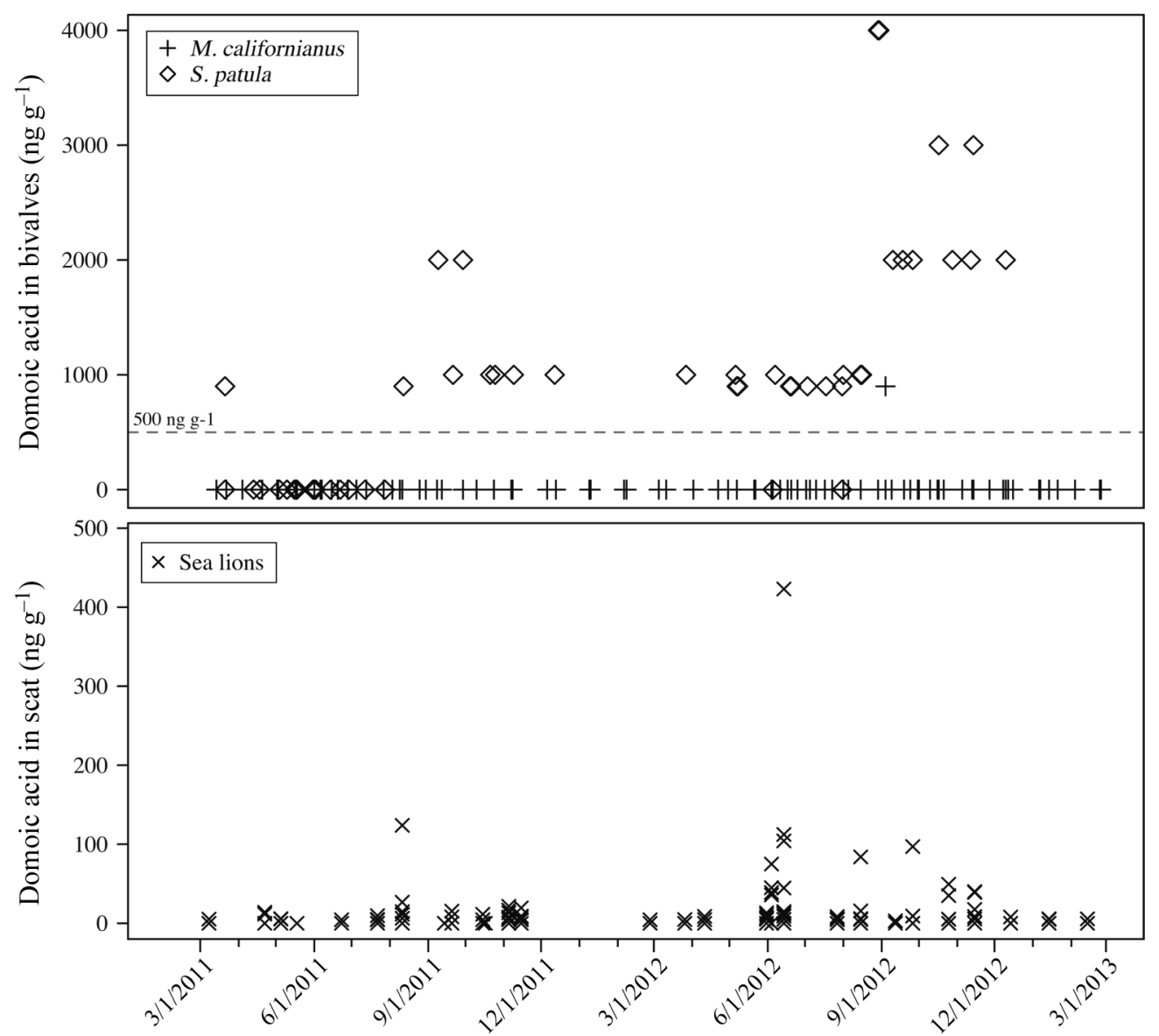

Fig. 5. Concentrations of domoic acid measured in California mussels Mytilus californianus, razor clams Siliqua patula, and sea lions (Steller Eumetopias jubatus and California Zalophus californianus) between March 2011 and March 2013. dashed line indicates the detection limit of $500 \mathrm{ng} \mathrm{g}^{-1}$ and represents concentrations reported by the Washington Department of Health of $<1000 \mathrm{ng} \mathrm{g}^{-1}$. All samples during this time period were below the human regulatory limit of $20000 \mathrm{ng} \mathrm{g}^{-1}$

their diet. To date, only low concentrations of saxitoxin have been reported in stranded Steller sea lions in Alaska (Lefebvre et al. 2016). However, given that those samples were obtained from dead stranded animals and several were pups or aborted fetuses (Lefebvre et al. 2016), the concentrations may not represent the total exposure level as found in fresh samples obtained from live animals. In the current study, scats containing pollock acted as the driver of the high prevalence and concentrations of saxitoxin observed in spring 2011. The occurrence of pollock is primarily traced to a single collection day (18 May 2011) at Tatoosh Island complex, where 17 of 17 scats were positive for saxitoxin; 15 of these contained pollock. The low occurrence of pollock in scats in this study likely relates to their overall distribution, which is highest in the Bering Sea and Gulf of Alaska and lower along the coasts of Washington and Oregon (Bredesen et al. 2006). Pollock are a mid-water to benthic species that eat a variety of zooplankton and fishes and are the most common prey item in sea lion diet throughout much of Alaska (Sinclair \& Zeppelin 2002, Sigler et al. 2009).

\section{Comparison to nearshore bivalves}

In this and previous studies (Goldstein et al. 2008, Torres de la Riva et al. 2009), sea lions appear to act as indicators of offshore blooms, such as those occurring in the Juan de Fuca Eddy, before they are apparent in the nearshore waters. Past studies have found evidence for both co-occurrence of HAB toxins in marine mammals and in bivalves (Doucette et al. 2006, Lefebvre et al. 2010) and for a lack of correlation between the 2 (Scholin et al. 2000). While concentrations detected in the bivalves can signal an active or recent bloom, blooms occurring offshore or outside of the areas that bivalves are monitored may not be detected. Additionally, bivalves have different 
rates of toxin depuration, and depending on sampling frequency, there may not be apparent overlap in the bivalves and sea lion scats. For example, California mussels depurate PSTs in a span of 3 to $>12 \mathrm{wk}$ (Bricelj \& Shumway 1998), but depurate domoic acid in as little as 2 wk (Whyte et al. 1995). Razor clams typically accumulate only low levels of PSTs (Trainer et al. 2003), whereas they hold domoic acid in their tissues for as long as 6 to 18 mo (Wekell et al. 1994). In our study, domoic acid was detected in sea lion scats somewhat prior to the spikes seen in nearshore shellfish, perhaps indicating that the sea lions were either foraging in areas of blooms prior to those waters making it nearshore or that their prey species traveled through or foraged in these areas. Similarly, high concentrations of saxitoxin (>200 $\mathrm{ng} \mathrm{g}^{-1}$ ) were detected in sea lion scat prior to PST concentrations in bivalves reaching levels above the regulatory limit. Of particular interest is the occurrence of saxitoxin in sea lion scat during winter and early spring when low $\left(<380 \mathrm{ng} \mathrm{g}^{-1}\right)$ to no PSTs were detected in bivalves and when blooms typically do not occur. If this exposure resulted from Alexandrium cysts being resuspended into the water column, it is possible that this occurred outside of areas that are presently sampled for bivalves or that the depuration period had already passed, and thus was not detected in the bivalves. A more comprehensive analysis of plankton and toxin movement through the food web is needed to fully understand this dynamic system.

\section{Study limitations}

Despite many compelling findings, there are some limitations to this study's interpretation. There is no literature on what effects weathering might have on the toxin content in scats deposited on haulout sites, and the toxin concentrations in this study are assumed to represent the full amount at the time of deposition. Because both saxitoxin and domoic acid are flushed from the digestive system quickly, it is likely that toxins in scats were from a recent feeding event (Jensen et al. 2015); however, hard parts in a single scat may not represent all fish eaten or all fish from the most recent meal. Biases in hard-part scat analysis, such as identifying prey structures, degradation of bones in digestion, and different passage and recovery rates of fish ingested (Tollit et al. 2015), could also have affected our results. Although we identified all prey structures to improve documentation of consumed prey (Tollit et al. 2015), it is still possible that prey species that had very friable bones or that were not wholly consumed (e.g. depredated salmon from troll fisheries) were not documented. FO describes the presence or absence of a prey item without enumerating the number of fish eaten or estimating volume or biomass of eaten prey, which likely limited our ability to evaluate the contribution of each prey species in the diet. Future studies on exposure of sea lions to HAB toxins would benefit from employing newly developed molecular techniques that allow quantifying diet and prey biomass (Deagle et al. 2013, Thomas et al. 2016).

In addition, given the previously discussed limitations of the saxitoxin ELISA, our saxitoxin results should be interpreted with caution. Few publications have attempted to compare or validate the saxitoxin ELISA in marine mammal feces or tissues with other methods, although some authors have performed matrix testing to avoid false positives or negatives (e.g. Lefebvre et al. 2016). Due to the limited-cross reactivity with other PST toxins, we must assume that the saxitoxin ELISA potentially underestimated the full sample toxicity. For example, in Sequim Bay, Washington, the gonyautoxins GTX1,4, GTX2,3, and neosaxitoxin were more prevalent in Alexandrium spp. isolates compared to saxitoxin itself (Lefebvre et al. 2008). Further, detection of algal toxins in the scats remains an underestimate of the full amount of toxins the sea lions were exposed to because it only reflects the toxin that was passed through digestion and does not account for the amount initially ingested.

\section{Consequences of toxin exposure}

Toxin concentrations measured in this study are not likely to have caused acute illness and likely indicate very low concentrations metabolized into tissues. Domoic acid concentrations in this study were well below those measured in scat from harbor seals Phoca vitulina and northern fur seals Callorhinus ursinus exhibiting acute domoic acid toxicity (Lefebvre et al. 2010, McHuron et al. 2013), but were comparable to concentrations in California sea lions with acute and chronic symptoms (Lefebvre et al. 1999, Goldstein et al. 2008). The concentrations were higher than those measured in stranded, harvested, and live pinnipeds in Alaska (Lefebvre et al. 2016), but lower than maximum concentrations reported in stranded northern fur seals in Alaska (Lefebvre et al. 2010) and free-ranging harbor seals in Scotland (Jensen et al. 2015). Both acute and chronic pathologies of domoic acid toxicity have been described in marine mammals (Goldstein et al. 2008). Symptoms 
of chronic domoic acid exposure include epilepsy, compromised foraging behavior and navigation, and reproductive failure (Brodie et al. 2006, Goldstein et al. 2008, Thomas et al. 2010).

It is not known what concentrations of saxitoxin cause mortality in marine mammals, but the concentrations measured in this study fall below the lethal total dose in humans of 1-4 mg (James et al. 2010). PSTs have been suspected in mass mortalities of humpback whales Megaptera novaeangliae, Mediterranean monk seals Monachus monachus, and bottlenose dolphins Tursiops truncatus, although concentrations in feces and other body fluids were not available for comparison to this study (Fire \& Van Dolah 2012). Saxitoxin concentrations in this study were higher than those reported in 13 marine mammal species sampled in Alaska (Lefebvre et al. 2016), but within the range of PSTs detected in free-ranging and stranded harbor seals in Scotland (Jensen et al. 2015) and North Atlantic right whales Eubalaena glacialis in the Bay of Fundy, Canada (Doucette et al. 2006). Durbin et al. (2002) suggested that repeated exposure to PSTs could affect diving capabilities, such as causing longer surfacing time after a dive as observed in right whales. Bogomolni et al. (2016) found that repeated exposure to low concentrations of saxitoxin increased phocine distemper virus in harbor seal lymphocytes and suggested that monitoring low levels of saxitoxin is important for understanding proliferation of diseases such as morbillivirus infection.

While concentrations in feces represent exposure, domoic acid measured in feces is frequently orders of magnitude higher than concentrations in the urine or serum, which are better indicators of the amounts metabolized (Goldstein et al. 2008, Lefebvre et al. 2010). Although sea lions have a high digestion efficiency of fish ( $>90 \%$, Rosen \& Trites 2000), the assimilation efficiency of these HAB toxins is not known. In terrestrial mammal species, only about $4-7 \%$ of ingested domoic acid is absorbed across the digestive tract (Truelove et al. 1997). The amount of saxitoxin absorbed by the digestive tract has not been reported in mammals; however, there is evidence in both humans (García et al. 2004) and whales (Doucette et al. 2006) of biotransformation of saxitoxin into other derivatives.

\section{CONCLUSIONS}

In conclusion, this study presents evidence of lowlevel exposure to saxitoxin and domoic acid in both Steller and California sea lions on the Washington coast and suggests that prey with relatively low occurrence in the diet may lead to significant algal toxin transfer up the food chain. While chronic exposure to domoic acid has been well documented in California sea lions (Goldstein et al. 2008), it is unclear what concentrations induce toxicity and how those compare to the concentrations measured in this study. Low level, chronic PST toxicity in wildlife has not been documented, although several authors have proposed possible effects, including immunomodulatory effects in harbor seals (Durbin et al. 2002, Bogomolni et al. 2016). What effects either chronic or acute algal toxin exposure may have at the population level remains unknown. Our findings suggest that generalist predators with a more diverse diet may not have any respite from exposure to, or the effects of, marine algal toxins as compared to predators that specialize in specific prey items. Sampling at a finer timescale (e.g. weekly or monthly) may be necessary for understanding the role of infrequent prey species in transfer of algal toxins to top predators. This study reaffirms previous studies documenting that marine mammals can be exposed to algal toxins through their prey outside of the expected algal bloom seasons (Twiner et al. 2011) and suggests further investigation into food web transfer of precipitated cells and dormant cysts or long-term retention of algal toxins in the West Coast food web.

Acknowledgements. This study was conducted as part of a Master's thesis at Western Washington University completed by A.M.A. in June 2016. Research was funded by the Makah Tribe through the Olympic Coast National Marine Sanctuary and a NOAA Fisheries' Species Recovery Grant Program and conducted under NMFS research permit nos. 14326 and 13430 awarded to NOAA's National Marine Mammal Laboratory (NMML), Seattle, WA. Special thanks to Russell Svec at Makah Fisheries Management and to the Makah Tribal Council for their support. This project was possible thanks to the work of Elizabeth Frame and Susan Riemer. Thank you to Adi Hanein, Shelley Lankford, and staff at the Washington Department of Health for providing coastal bivalve data. We thank the staff from the Makah Tribe, Quileute Tribe, and Washington Department of Fish and Wildlife for collecting the bivalve samples. Thank you to Pat Gearin and Merrill Gosho at NMML for assisting in sample collection. We thank Brian Bingham and Suzanne Strom for input and assistance in data analysis and manuscript editing.

\section{LITERATURE CITED}

Agresti A (2007) An introduction to categorical data analysis, 2nd edn. John Wiley \& Sons, Hoboken, NJ

AOAC (Association of Official Agricultural Chemists) (1965) Biological method. In: Horowitz W (ed) Official methods of analysis of the Association of Official Agricultural Chemists, 10th edn. AOAC, Washington, DC, p 282-284 
APHA (American Public Health Association) (1970) Recommended procedures for the examination of water and shellfish, 4th edn. APHA, New York, NY

Bogomolni AL, Bass AL, Fire S, Jasperse L and others (2016) Saxitoxin increases phocine distemper virus replication upon in-vitro infection in harbor seal immune cells. Harmful Algae 51:89-96

Bredesen EL, Coombs AP, Trites AW (2006) Relationship between Steller sea lion diets and fish distributions in the eastern North Pacific. In: Trites A, Atkinson S, DeMaster D, Fritz L, Gelatt T, Rea L, Wynne K (eds) Sea lions of the world. Alaska Sea Grant College Program, University of Alaska Fairbanks, Fairbanks, AK, p 131-140

* Bricelj VM, Shumway SE (1998) Paralytic shellfish toxins in bivalve molluscs: occurrence, transfer kinetics, and biotransformation. Rev Fish Sci 6:315-383

* Brodie EC, Gulland FMD, Greig DJ, Hunter M and others (2006) Domoic acid causes reproductive failure in California sea lions (Zalophus californianus). Mar Mamm Sci 22:700-707

Butman B, Aretxabaleta AL, Dickhudt PJ, Dalyander PS and others (2014) Investigating the importance of sediment resuspension in Alexandrium fundyense cyst population dynamics in the Gulf of Maine. Deep Sea Res Part II Top Stud Oceanogr 103:79-95

Costa PR, Baugh KA, Wright B, RaLonde R and others (2009) Comparative determination of paralytic shellfish toxins (PSTs) using five different toxin detection methods in shellfish species collected in the Aleutian Islands, Alaska. Toxicon 54:313-320

Deagle BE, Thomas AC, Shaffer AK, Trites AW, Jarmon SN (2013) Quantifying sequence proportions in a DNAbased diet study using Ion Torrent amplicon sequencing: Which counts count? Mol Ecol Resour 13:620-633

* Doucette GJ, Cembella AD, Martin JL, Michaud J, Cole TVN, Rolland RM (2006) Paralytic shellfish poisoning (PSP) toxins in North Atlantic right whales Eubalaena glacialis and their zooplankton prey in the Bay of Fundy, Canada. Mar Ecol Prog Ser 306:303-313

* Duffy EJ, Beauchamp DA (2011) Rapid growth in the early marine period improves the marine survival of Chinook salmon (Oncorhynchus tshawytscha) in Puget Sound, Washington. Can J Fish Aquat Sci 68:232-240

Durbin E, Teegarden G, Campbell R, Cembella A, Baumgartner MF, Mate BR (2002) North Atlantic right whales, Eubalaena glacialis, exposed to paralytic shellfish poisoning (PSP) toxins via a zooplankton vector, Calanus finmarchicus. Harmful Algae 1:243-251

Fire SE, Van Dolah FM (2012) Marine biotoxins: emergence of harmful algal blooms as health threats to marine wildlife In: Aguirre AA, Ostfeld R, Daszak P (eds) New directions in conservation medicine: applied cases of ecological health. Oxford University Press, New York, NY, p 374-389

Frame E, Lefebvre K (2013) ELISA methods for domoic acid quantification in multiple marine mammal species and sample matrices. Tech Memo NMFS-NWFSC-122. US Department of Commerce, NOAA, Seattle, WA

* García C, del Bravo MC, Lagos M, Néstor L (2004) Paralytic shellfish poisoning: post-mortem analysis of tissue and body fluid samples from human victims in the Patagonia fjords. Toxicon 43:149-158

Gearin PJ, Melin SR, DeLong RL, Gosho ME, Jeffries SJ (2017) Migration patterns of adult male California sea lions (Zalophus californianus). Tech Memo NMFS-
AFSC-346. US Department of Commerce, NOAA, Seattle, WA

KGoldstein T, Mazet JAK, Zabka TS, Langlois G and others (2008) Novel symptomatology and changing epidemiology of domoic acid toxicosis in California sea lions (Zalophus californianus): an increasing risk to marine mammal health. Proc R Soc Lond B Biol Sci 275:267-276

*Humpage AR, Magalhaes VF, Froscio SM (2010) Comparison of analytical tools and biological assays for detection of paralytic shellfish poisoning toxins. Anal Bioanal Chem 397:1655-1671

* Ichimi K, Montani S (2001) Effects of deposit feeder ingestion on the survival and germination of marine flagellate cysts. Fish Sci 67:1178-1180

* James KJ, Carey B, O'Halloran J, van Pelt FNAM, Škrabáková Z (2010) Shellfish toxicity: human health implications of marine algal toxins. Epidemiol Infect 138: 927-940

Jensen SK, Lacaze JP, Hermann G, Kershaw J, Brownlow A, Turner A, Hall A (2015) Detection and effects of harmful algal toxins in Scottish harbour seals and potential links to population decline. Toxicon 97:1-14

* Jester RJ, Baugh KA, Lefebvre KA (2009) Presence of Alexandrium catenella and paralytic shellfish toxins in finfish, shellfish and rock crabs in Monterey Bay, California, USA. Mar Biol 156:493-504

Kwong RWM, Wang WX, Lam PKS, Yu PKN (2006) The uptake, distribution and elimination of paralytic shellfish toxins in mussels and fish exposed to toxic dinoflagellates. Aquat Toxicol 80:82-91

KLefebvre KA, Powell CL, Busman M, Doucette GJ and others (1999) Detection of domoic acid in northern anchovies and California sea lions associated with an unusual mortality event. Nat Toxins 7:85-92

* Lefebvre KA, Dovel SL, Silver MW (2001) Tissue distribution and neurotoxic effects of domoic acid in a prominent vector species, the northern anchovy Engraulis mordax. Mar Biol 138:693-700

Lefebvre KA, Bargu S, Kieckhefer T, Silver MW (2002) From sandabs to blue whales: the pervasiveness of domoic acid. Toxicon 40:971-977

* Lefebvre KA, Bill BD, Erickson A, Baugh KA and others (2008) Characterization of intracellular and extracellular saxitoxin levels in both field and cultured Alexandrium spp. samples from Sequim Bay, Washington. Mar Drugs 6:103-116

Lefebvre KA, Robertson A, Frame ER, Colegrove KM and others (2010) Clinical signs and histopathology associated with domoic acid poisoning in northern fur seals (Callorhinus ursinus) and comparison of toxin detection methods. Harmful Algae 9:374-383

Lefebvre KA, Quakenbush L, Frame E, Huntington KB and others (2016) Prevalence of algal toxins in Alaskan marine mammals foraging in a changing arctic and subarctic environment. Harmful Algae 55:13-24

Kopes VM, Lopes AR, Costa P, Rosa R (2013) Cephalopods as vectors of harmful algal bloom toxins in marine food webs. Mar Drugs 11:3381-3409

* MacFadyen A, Hickey BM, Foreman MGG (2005) Transport of surface waters from the Juan de Fuca eddy region to the Washington coast. Cont Shelf Res 25:2008-2021

*McCabe RM, Hickey BM, Kudela RM, Lefebvre KA and others (2016) An unprecedented coastwide toxic algal bloom linked to anomalous ocean conditions. Geophys Res Lett 43:10366-10376 
McHugh ML (2013) The chi-square test of independence. Biochem Med (Zagreb) 23:143-149

McHuron E, Greig DJ, Colegrove KM, Fleetwood M and others (2013) Domoic acid exposure and associate clinical signs and histopathology in Pacific harbor seals (Phoca vitulina richardii). Harmful Algae 23:28-33

Miller A, Trites AW, Maschner DG (2005) Ocean climate changes and the Steller sea lion decline. Arct Res United States 19:54-63

NMFS (National Marine Fisheries Service) (2013) Status review of the eastern distinct population segment of Steller sea lion (Eumetopias jubatus). Protected Resources Division, Alaska Region, National Marine Fisheries Service, Juneau, AK

Oksanen J, Blanchet FG, Friendly M, Kindt R and others (2017) vegan: Community Ecology Package. R package version 2.4-4. https://CRAN.R-project.org/package= vegan

Orr AJ, Laake JL, Dhruv MI, Banks AS, DeLong RL, Huber HR (2003) Comparison of processing pinniped scat samples using a washing machine and nested sieves. Wildl Soc Bull 31:253-257

Orr AJ, Van Blaricom GR, DeLong RL, Cruz-Escalona VH, Newsome SD (2011) Intraspecific comparison of diet of California sea lions (Zalophus californianus) assessed using fecal and stable isotope analyses. Can J Zool 89: 109-122

Quilliam MA, Xie M, Hardstaff WR (1995) Rapid extraction and cleanup for liquid chromatography determination of domoic acid in unsalted seafood. J AOAC Int 78:543-554

R Core Team (2015) R: a language and environment for statistical computing. R Foundation for Statistical Computing, Vienna. www.r-project.org/

Riemer S, Wright BE, Brown RF (2011) Food habits of Steller sea lions (Eumetopias jubatus) off Oregon and northern California, 1986-2007. Fish Bull 108:369-381

Rosen DAS, Trites AW (2000) Digestive efficiency and drymatter digestibility in Steller sea lions fed herring, pollock, squid, and salmon. Can J Zool 78:234-239

Scholin CA, Gulland F, Doucette GJ, Benson S and others (2000) Mortality of sea lions along the central California coast linked to a toxic diatom bloom. Nature 403:80-84

Schwinghamer P, Hawryluk M, Powell C, MacKenzie CH (1994) Resuspended hypnozygotes of Alexandrium fundyense associated with winter occurrence of PSP in inshore Newfoundland waters. Aquaculture 122:171-179

Sigler MF, Tollit DJ, Vollenweider JJ, Thedinga JF and others (2009) Steller sea lion foraging response to seasonal changes in prey availability. Mar Ecol Prog Ser 388: 243-261

Sinclair EH, Zeppelin TK (2002) Seasonal and spatial differences in diet in the western stock of Steller sea lions (Eumetopias jubatus). J Mammal 83:973-990

Thomas K, Harvey JT, Goldstein T, Barakos J, Gulland F (2010) Movement, dive behavior, and survival of California sea lions (Zalophus californianus) posttreatment for domoic acid toxicosis. Mar Mamm Sci 26:36-52

* Thomas AC, Deagle BE, Eveson JP, Harsch CH, Trites AW (2016) Quantitative DNA metabarcoding: improved esti-

Editorial responsibility: Antonio Bode, A Coruña, Spain mates of species proportional biomass using correction factors derived from control material. Mol Ecol Resour 16:714-726

Tollit DJ, Schulze AD, Trites AW, Olesiuk PF and others (2009) Development and application of DNA techniques for validating and improving pinniped diet estimates. Ecol Appl 19:889-905

Tollit DJ, Wong MA, Trites AW (2015) Diet composition of Steller sea lions (Eumetopias jubatus) in Frederick Sound, southeast Alaska: a comparison of quantification methods using scats to describe temporal and spatial variabilities. Can J Zool 93:361-376

Torres de la Riva G, Johnson CK, Gulland FMD, Langlois GW, Heyning JE, Rowles TK, Mazet JAK (2009) Association of an unusual marine mammal mortality event with Pseudo-nitzschia spp. blooms along the southern California coastline. J Wildl Dis 45:109-121

* Trainer VL, Hickey BM, Horner RA (2002) Biological and physical dynamics of domoic acid production off the Washington coast. Limnol Oceanogr 47:1438-1446

Trainer VL, Eberhart BTL, Wekell JC, Adams NG, Hanson L, Cox F, Dowell J (2003) Paralytic shellfish toxins in Puget Sound, Washington State. J Shellfish Res 22: 213-223

* Truelove J, Mueller R, Pulido O, Martin L, Fernie S, Iverson F (1997) 30-day oral toxicity study of domoic acid in cynomolgus monkeys: lack of overt toxicity at doses approaching the acute toxic dose. Nat Toxins 5:111-114

Turner AD, Stubbs B, Coates L, Dhanji-Rapkova M and others (2014) Variability of paralytic shellfish toxin occurrence and profiles in bivalve molluscs from Great Britain from official control monitoring as determined by precolumn oxidation liquid chromatography and implications for applying immunochemical tests. Harmful Algae 31:87-99

* Twiner MJ, Fire S, Schwacke L, Davidson L and others (2011) Concurrent exposure of bottlenose dolphins (Tursiops truncatus) to multiple algal toxins in Sarasota Bay, Florida, USA. PLOS ONE 6:e17394

Vigilant VL, Silver MW (2007) Domoic acid in benthic flatfish on the continental shelf of Monterey Bay, California, USA. Mar Biol 151:2053-2062

WWekell JC, Gauglitz EJ Jr, Barnett HJ, Hatfield CL, Simons D, Ayres D (1994) Occurrence of domoic acid in Washington state razor clams (Siliqua patula) during 19911993. Nat Toxins 2:197-205

*White CL, Schuler KL, Thomas NJ, Webb JL and others (2013) Pathogen exposure and blood chemistry in the Washington, USA population of northern sea otters (Enhydra lutris kenyoni). J Wildl Dis 49:887-899

Wittmaack C, Lahvis GP, Keith EO, Self-Sullivan C (2015) Diagnosing domoic acid toxicosis in the California sea lion (Zalophus californianus) using behavioral criteria: a novel approach. Zoo Biol 34:314-320

Whyte JNC, Ginther NG, Townsend LD (1995) Accumulation and depuration of domoic acid by the mussel Mytilus californianus. In: Lassus P, Arzul G, Erard E, Gentien P, Marcaillou C (eds) Harmful marine algal blooms. Lavoisier Intercept, Paris, p 531-537

Submitted: November 3, 2016; Accepted: September 21, 2017 Proofs received from author(s): November 9, 2017 